\title{
FRANKENSTEIN E CYBORGS: PISTAS NO CAMINHO DA CIÊNCIA INDICAM O "NOVO EUGENISMO"
}

\author{
ANDRÉ LUIZ SILVA* \\ ANDRÉA MORENO**
}

\section{RESUMO}

Este estudo analisa as atuais possibilidades de intervenções no corpo em busca de ampliá-lo, tornando-o mais bem adaptado às condições contemporâneas. Através das lentes da Eugenia do final do século XIX e início do XX, propomos buscar elementos que nos ajudem a pensar nossa atmosfera. De posse de reportagens coletadas em jornais e revistas de grande circulação e atentos aos dois períodos, identificamos muitas das novas tecnologias do corpo carreadoras de permanências daquilo que foi a busca pelo corpo melhorado. Denominadas "novo eugenismo", as atuais introjeções tecnológicas assumem características próprias do nosso tempo, ao passo que guardam semelhanças profundas com aquilo que se chamou Eugenia.

PALAVRAS-CHAVE: eugenia - ciência - adaptações do corpo

\section{INTRODUÇÃO}

O doutor Darwin e alguns fisiologistas alemães têm dado a entender que o fato sobre o qual se fundamenta esta ficção não é impossível de acontecer. ${ }^{1}$

(Mary Shelley)

Drojeto Genoma, células tronco, clonagem, doping genético, seleção 1 sexual, coração de titânio, nanotecnologia. A mídia nos aponta: Estamos a um passo da criação de um "super-homem".

\footnotetext{
* Acadêmico da Universidade Federal de Viçosa.

** Doutora em Educação pela Unicamp e professora da Universidade Federal de Viçosa.
} 
O desenvolvimento científico e tecnológico nos traz, a cada dia, novas possibilidades de intervenções no corpo. As necessidades de produção e acúmulo que rondam o contexto atual nos empurram para a busca do desempenho, do ponto ótimo de performance. O corpo tornou-se obsoleto. As introjeções tecnológicas surgem a fim de "turbinar" a máquina humana, ampliando-a, melhorando-a, melhor adaptando-a às necessidades ambientais. É como se a seleção "natural" de Darwin ganhasse outros contornos e nós, à mercê das leis evolutivas, tivéssemos de nos adaptar.

Há tempos a humanidade presenciou fenômeno semelhante, em que a busca pela força da nação fez surgir a ciência da melhoria da espécie. A seleção natural foi pensada a partir de contornos laboratoriais, como se o homem quisesse assumir a direção das leis naturais e, pelas próprias mãos, selecionar os aptos, assegurando assim o nascimento de indivíduos ampliados e melhorados.

A esse fenômeno denominamos eugenia. $\mathrm{O}$ medo e o tabu fazem fechar nossos olhos às semelhanças daquele regime de horror, nos fazem querer esquecer, quase negar aquilo que hoje pode configurar-se como permanência. Será que as atuais intervenções no corpo não guardam semelhança com aquilo que, outrora, se chamou eugenia? Poderíamos chamar de novo eugenismo a tentativa de criar um homem melhorado?

Sem a pretensão de responder objetivamente a essas questões, propomos com este texto pensar as possibilidades tecnológicas para assim nos colocar criticamente diante da atmosfera que nos circunda. Ler, a partir das lentes da eugenia, o fenômeno que nos ronda, porém não numa perspectiva alarmante, ou mesmo com a intenção de apontar o certo ou o errado. Olhamos para o passado a fim de levantarmos indícios e questões que possam, hoje, nos auxiliar a pensar as novas configurações do corpo.

\section{FRANKENSTEIN: ARTE, CIÊNCIA E A REINVENÇÃO DO HUMANO}

Coletava ossos dos necrotérios e profanava, com os dedos, os recônditos do corpo humano. Numa câmara solitária, ou antes, numa sela, na parte superior da casa, separada por uma galeria e uma escada de todos os outros aposentos, eu montara meu laboratório da vida humana.

O necrotério e o matadouro eram minhas fontes usuais de suprimento. $^{2}$

(Mary Shelley) 
A literatura moderna nos conta, em alguns de seus clássicos, o descobrir ${ }^{3}$ da pele, "mostrando-nos", através dos corpos de seus personagens, as vísceras e o sangue. Assim é Frankenstein, um monstro que nos revela a fascinação do homem sobre a carne, trazendo o corpo virado e revirado, um amontoado de músculos, ossos e pele conectos por linhas e vitalizados pela eletricidade. Esse "monstro" da literatura expõe o corpo como material biológico: um condensado de células, tecidos e órgãos desordenados, reordenados numa aparência que desperta o asco. Frankenstein tem um corpo composto por partes humanas, porém sem a "perfeição" do ser humano.

Esse personagem nasce no período de sobressalto da ciência, momento em que o humano toma conotações diferentes das ditadas pelas antigas referências religiosas. $\mathrm{O}$ corpo como possibilidade de investigação, entretanto, já havia sido descoberto períodos antes do aparecimento de Frankenstein. ${ }^{4}$

A modernidade caracteriza a entrada em cena de um interesse pelo corpo. A aquisição desse papel central só foi possível devido a uma série de mudanças nas maneiras de ver e pensar. Questões como a materialidade, a urbanização, dentre outras, vão influir fortemente nesta nova concepção de mundo. Vejamos algumas:

A Revolução Francesa pode ser definida como marco do processo de descentralização da corte, a qual cede lugar à urbanização, e como transformadora do "sujeito divino em sujeito humano" muito mais trabalhador e menos contemplativo, um ser voltado para a materialidade das coisas. $\mathrm{O}$ trabalho profissional torna-se a prática eleita capaz de desenvolver a efetiva realização da virtude: "o ascetismo foi levado para fora dos mosteiros e transferido para a vida profissional", contribuindo para a sedimentação da moderna ordem econômica e de produção(SILVA, 1999, p. 10).

Para Silva (1999), a descrença no sobre-humano colocou o homem numa posição isolada, solitária, abandonada por Deus, cujos poderes são por ele assumidos. Isso o levou a questionar a si, a sua liberdade e a concretude da vida. No momento em que "Deus morre", o corpo é visto como elemento materializado, dessacralizado.

O desenvolvimento racional oferece inúmeros objetos a serem estudados à luz da ciência. O ser humano torna-se objeto conhecedor e de conhecimento. A racionalidade típica do indivíduo moderno o autoriza como conhecedor da natureza, ou mesmo como seu senhor, apto a nela intervir e 
manipular. Logo mais, o resultante destes estudos ganha inserção na vida das pessoas, influenciando seus hábitos (SILVA, 1999, p. 10).

Tudo isso fornece elementos para a consolidação de uma nova forma de ver, pensar e sentir. Seria a construção da subjetividade, por meio da incorporação dos vários discursos, vivências, normas, valores etc. a partir de diversas instituições ou pessoas. Nesta perspectiva, Naffah Neto (1995, p. 198) expõe subjetividade

como uma envergadura interior, de vazio, capaz de acolher, dar abrigo e morada às experiências de vida: percepções, pensamentos, fantasias, sentimentos. Ou se quisermos usar um só termo: afetos, diferentes expressões de como somos afetados pelo mundo. A subjetividade nesse sentido tem o sentido de ethos (que etimologicamente significa abrigo, morada).

Os séculos XVII e XVIII tornaram-se fundamentais para a estruturação da medicina, devido ao desenvolvimento radical quanto às noções técnicas. É aqui que se encontram as bases da ciência médica contemporânea, período marcado pelo grande desenvolvimento científico.

As técnicas e pesquisas acerca do corpo contribuem para sedimentar, juntamente com seus preceitos morais, o processo de subjetivação e individuação. Todos os elementos desta nova visão confluem para a formação de uma imagem individual na qual o corpo se revela como elemento de central importância. Daqui surgem os cuidados de si como práticas e técnicas para sentir o corpo, dando a ele a centralidade que o torna objeto de preocupações.

O corpo libertou-se da natureza, rompeu as amarras que o prendiam a um sistema que não mais condiz ao seu contexto e, neste momento, grande agitação se inicia na busca de armá-lo com todos os elementos capazes de intensificar a matéria e sua materialidade. Vários foram os estudos que surgiram no bojo dessas novas representações corporais. Várias foram as propostas, vários foram os objetivos, e neste meio aparece a ciência da melhoria da raça.

A eugenia surge como movimento político que visava melhorar a condição genética, partindo do princípio de controle do cruzamento seletivo aplicado à espécie humana, porém só veio adquirir status de ciência após o surgimento da genética, por volta de 1900 (HOBSBAWM, 1992). Sua decorrência é resultado de uma série de estudos caracteriza- 
dos como científicos a partir de meados do século XIX. Neste sentido, consolida-se como ciência ${ }^{5}$ que visa a melhoria da raça humana, fadada a desenvolver o melhoramento da espécie. Seus primeiros escritos datam de 1869, com o livro Hereditary Genius, de autoria de Francis Galton, considerado marco inicial para esta ciência. Sofrendo grande influência das teorias evolutivas de Darwin ${ }^{6}$ e de elementos da matemática, propôs um padrão original da raça.

Este é o meu objetivo: esta analogia ${ }^{7}$ mostra que deve haver uma média de capacidade mental obedecendo a certa constância nos habitantes das ilhas britânicas, e que os desvios dessa média, aqueles mais próximos da genialidade ou aqueles mais próximos da estupidez, devem seguir a lei que governa os desvios de todas as médias verdadeiras (GALTON apud BIZZO, 1995, p. 40).

O contexto europeu coloca-se como terreno fértil, ampliando inúmeras sociedades eugênicas pouco tempo após a solidificação das teorias de Galton. Por mais que as investidas eugênicas ganhassem cores diferentes, em diferentes locais, podemos dizer que em todos permaneceu a esperança de aprimoramento da espécie, da raça, da população. Num contexto em que o corpo passa a ser visto a partir de outras lentes e diante da necessidade de ampliá-lo, de melhor adaptá-lo, a Eugenia, com suas peculiaridades e saber próprio, vai intervir neste corpo.

Uma das primeiras obras literárias a representar para o público a possibilidade do corpo reorganizado, Frankenstein foi um marco. Mas a literatura não foi a única a trazer para o palco das artes o corpo visto por debaixo da pele. Vários foram os artistas que se enveredaram nesse tipo de publicação. ${ }^{8}$

Frankenstein não representou apenas o corpo mexido e remexido. Com toda sua fealdade e suas muitas características desagradáveis, ele se apresentava "forte", mais forte que um homem qualquer. Melhor? Talvez quanto à sua força física sim, mas esta era apenas uma invenção na qual deviam padecer as amarguras de um ser malfeito, porém apenas no sentido da aparência física, o que podemos verificar nas próprias palavras de "Frank".

Era na verdade mais ágil [...], mais rude e resistente, podendo adaptarme a uma dieta grosseira. Podia suportar os rigores do calor e do frio 
com menos dano para o meu organismo. Minha estatura excedia em muito a do homem normal (SHELLEY, 2004, p. 114). ${ }^{9}$

Mesmo sendo a materialização da vitória do homem sobre a morte, seu aspecto grotesco o colocava à margem. Apesar de feio, este monstro representou a reinvenção do humano. ${ }^{10}$ A possibilidade era respaldada por uma ciência que começava a se popularizar. "Frank" representou naquele momento a imagem do Cyborg. ${ }^{11}$

\section{CYBERNETIC ORGANISM: INTROJEÇÕES TECNOLÓGICAS E NOVAS POSSIBILIDADES DE CORPO}

Temos, pois, a idéia de natureza como vida, operação natural da vida em oposição a qualquer movimento teológico: o corpo humano só é corpo na medida que traz em si mesmo o inacabado, isto é, promessa permanente de autocriação, e é isso que faz dele um enigma que a tecnociência pretende negar.

(A. Novaes)

Uma das características do contemporâneo é a promiscuidade, que pode ser entendida como a junção homem/máquina, traduzida pela fusão entre ciência e política, tecnologia e sociedade, natureza e cultura. Não existe pureza nestes elementos, há uma total mistura, não cabendo a algo ser só social, natural ou puramente humano. Difícil é dizer onde termina o natural e onde inicia o artifício, os limites tornam-se tênues, caminhando para a fusão completa, como amálgama. Presenciamos a perda dos contornos humanos à medida que a biotecnologia avança (SANT'ANNA, 2001).

No trato com a máquina e com o homem, vemos máquinas que se incorporam, literalmente, ao ser, tornando-os "artificiais", ou ainda é possível ver andróides que apresentam características humanas melhoradas. Várias são as perspectivas destas tecnologias, mas carregam consigo o humano como referência. Segundo sistematizações, as tecnologias "cyborguianas" podem ser: 1. restauradoras: permitem restaurar funções e substituir órgãos e membros perdidos. Aqui podemos destacar os transplantes de órgãos naturais e artificiais, as próteses de membros, a terapia com células-tronco etc.; 2. normalizadoras: retor- 
nam as criaturas a uma indiferente normalidade. Diz respeito a tecnologias que se incorporam tão intimamente que impossibilitam a identificação do artifício; 3. reconfiguradoras: criam criaturas pós-humanas que são iguais aos seres humanos e, ao mesmo tempo, diferentes deles. Robôs, humanóides; e 4. melhoradoras: criam criaturas melhoradas, relativamente ao ser humano. Dentre estas últimas podemos destacar como possibilidades o Projeto Genoma, o doping genético, dentre outros (GRAY apud SILVA, T., 2000, p. 14).

Particularmente, gostamos de pensar as tecnologias restauradoras, normalizadoras e melhoradoras como eugenizadoras. Tecnologias que carregam características da eugenia como a busca pelo padrão original da raça e melhoria da espécie.

É fácil perceber as investidas tecnocientíficas no cenário fictício. O cinema, principalmente o hollywoodiano, despeja uma infinidade de filmes que trazem o ser híbrido para a tela, como: Robocop, dirigido por Paul Verhoever, 1987; Matrix, por Wachowski, 1999; Blade Runner, por Ridley Scott, 1982 e outros. Podemos dizer que o desenvolvimento científico e tecnológico deflagrou, nos anos 80 e 90, essas formas artísticas de se tratar o corpo.

Também, em reportagens veiculadas pela mídia identificamos possibilidades que antes só eram idealizadas na imaginação dos cineastas. Como exemplo, podemos citar o artigo "Tudo é verdade", veiculado na revista Veja de 12 de novembro de 2003. Este artigo traz como tema a possibilidade de produção de órgãos e tecidos artificiais, ressaltada pela recente terapia com o uso de sangue em pó, a produção de coração de titânio, pele de silicone e outros órgãos feitos a partir de substâncias que interagem com o organismo, prometendo estimular a reprodução celular e inibir a rejeição.

A edição de 11 de junho de 2003 da revista Veja trouxe em sua reportagem de capa novas descobertas científicas que prometem retardar o relógio biológico, mantendo-se "jovem dos 30 aos 60 anos".

A grande ocorrência desse tipo de pesquisa nos faz pensar as configurações que a morte assume no momento que é vista como disfunção orgânica, cujos mecanismos são desvendados pelas descobertas científicas.

A riqueza era uma finalidade secundária, mas quanta glória haveria de coroar a descoberta que permitisse banir a doença do organismo hu- 
mano, tornando o homem invulnerável a todas as mortes (SHELLEY, 2004, p. 43-44). ${ }^{12}$

As possibilidades de intervenção no corpo doente vão se afirmando, retardando tanto o processo de envelhecimento quanto a própria morte. Em contrapartida, a descrença no transcendental resultou numa "redução da expectativa de vida". ${ }^{13} \mathrm{O}$ que antes podia se referir à eternidade hoje se traduz em 70, 80, 90 anos. Percebemos com isso uma busca por fórmulas capazes de prolongar a vida, a matéria (SILVA, 2001, p. 69).

A valorização do corpo, dada sua materialidade, esbarra-se em questões e problemas da própria materialidade, como o mau funcionamento orgânico, a morte, o fim. A morte de Deus, antes mencionada, remete prazos à vida. E é na expectativa da imortalidade ${ }^{14}$ que se fundam as intervenções da tecnociência, ou, como dito anteriormente, as tecnologias "cyborguianas".

Ao analisarmos a expectativa da imortalidade, apoiados nas bases fisiológicas e bioquímicas, percebemos uma divergência entre tais bases e o imortal. O corpo biológico é finito, suas complexas redes e estruturas fatalmente se desestabilizam. É neste momento que um ou outro sucumbe. Ou a expectativa imortal pára de povoar os sonhos das pessoas, ou o corpo biológico é substituído, superando os entraves da matéria finita.

A alma não poderia habitar o corpo eternamente, estando sujeita à morte se a ele permanecer presa. Em nome da vida eterna é evocado um exorcismo que salva a alma do degradável corpo biológico, extirpa-a da contagem regressiva carnal para desfrutar da vida eterna. Deste prisma, o corpo tornou-se obsoleto por ser falho, condenando a alma à morte, à perda de suas potencialidades e de suas bagagens mentais. Neste sentido, damos não mais que um "adeus ao corpo", e a alma exorcizada viverá em paz dentro de um artefato eletrônico, puro, casto, divino. ${ }^{15}$

De volta à carne, questões relacionadas a ganho rápido de massa muscular e força são muito discutidas nas instâncias esportivas, que tentam controlar o uso de substâncias anabólicas através de testes antidoping. Este foi um dos temas abordados pelo jornal Folha de S. Paulo, de 23 de junho de 2000, ao prever a impossibilidade futura de se detectar tais substâncias, devido ao grau de adiantamento científico quanto à síntese desses hormônios.

Essas substâncias químicas materializam valores abstratos como força, resistência, beleza, entre outras características. Sendo vistas como 
ícones na medida em que são identificadas como a chave para as referidas qualidades e valores, trazem para o corpo do homem características que o torna ampliado e mais bem adaptado (SILVA, 2001).

Em 20 de fevereiro de 2002, a revista Veja anuncia os resultados da conclusão da decodificação do Projeto Genoma Humano. O jornal Folha de S. Paulo, do dia 3 de junho de 2003, p. 2 a 14, ao organizar o caderno especial "Futuro do esporte", traz previsões decorrentes dos últimos avanços tecnológicos, de ser possível identificar, através de estudos de genes, atletas potenciais, além de em breve ser possível, através da manipulação genética, colocar todas as variáveis ótimas numa só pessoa, dando um grande salto na construção de um superatleta.

Pesquisadores dos Estados Unidos e da Grã-Bretanha desenvolveram uma técnica que injeta genes em animais, fazendo com que a massa muscular aumente até $27 \%$ sem ser preciso o animal se exercitar. O jornal Folha de S. Paulo, de 23 de junho de 2000, p. 2, anuncia que "Ainda não foi aprovada a realização de testes em humanos, mas, se a pesquisa for até o fim, em quinze anos poderão surgir os primeiros "super-homens"'.

Pensando na perspectiva da procriação, uma pesquisa encomendada à Datafolha pelo jornal Folha de S. Paulo, de 3 de julho de 2000, p. A 17 , "mostra que $50 \%$ dos paulistanos escolheriam dar capacidade intelectual aos filhos, se a ciência permitisse". A pesquisa objetivou identificar qual, dentre muitas características, seria a mais desejada entre os entrevistados e mostrar também quais problemas levariam os possíveis pais a decidirem pelo aborto, caso a ciência fosse capaz de predizer os tipos de anomalias que poderiam acometer o bebê.

Esta pesquisa nos remete à clássica história das leis espartanas que, sob o domínio de Licurgo, obrigavam os pais a atirar os filhos mal nascidos a um despenhadeiro. As deformidades físicas de nada serviam num lugar onde se cultivavam homens para a guerra. Licurgo muito inspirou os ideais eugênicos, que pretensiosamente desejavam não cometer os mesmos erros daquele legislador. Pensar em escolher as qualidades dos filhos e, principalmente, se eles devem ou não viver antes mesmo de seu nascimento, nos faz pensar em novas configurações das leis espartanas, ou mesmo do eugenismo. Características próprias de um momento que carrega consigo elementos de outros.

A engenharia genética já possibilita grandes alterações na natureza e no homem, as possibilidades que se concretizam são justificadas 
por sua "neutralidade, objetividade e irrefutabilidade", situando-se em bases frágeis e que pouco a pouco são desconstruídas. Mas o fato é que este é um caminho sem volta e as transformações ocorridas, decorrentes de tais pesquisas, são irreversíveis (SILVA, 2001, p. 111).

Não somente o homem, mas toda a natureza há muito vêm sendo modificados em função de necessidades de produção ${ }^{16}$ e de consumo, o que gera aumento da tolerância quanto aos novos organismos (SANT'ANNA, 2001).

A biotecnologia movimenta milhões de dólares, colocando órgãos, células e tecidos dentro da ordem econômica. Nota-se uma prática científica mecanicista, em que a biotecnologia concebe o mundo e principalmente seus objetos de estudo numa visão reduzida, ou ainda que "os materiais de base da essência da vida não passam de meros 'parafusos' e 'tarraxas"” (CHIVA apud SANT'ANNA, 2001, p. 85).

A medicina caminha para uma prática preditiva e as possibilidades que se descortinam são as realizações dos mais profundos sonhos de uma sociedade medicalizada, higienizada e eugenizada. Saber os males que podem ou não acometer uma pessoa e ainda ler na dupla fita de DNA possíveis inclinações de caráter representam o futuro da norma.

O desenvolvimento tecnológico e científico vem pôr abaixo antigos mitos, criando novos. Portanto, o que se apresenta como evolução científica é o mito da cientificidade. Crença no progresso e na neutralidade, crença na ciência como panacéia capaz de extinguir todos os males (CARVALHO, 2001). Silva (2001, p. 39) afirma que

a ciência por seu caráter pragmático e reprodutor perante a realidade, não incluindo a tarefa de reflexão crítica sobre o seu próprio pensar, reduz, grandemente, a capacidade ética do ser humano.

O número de novas técnicas e novas possibilidades científicas de intervenção no corpo nos revela um dogmatismo quanto a seus fundamentos. Tais técnicas revelam um desejo de normalizar, suprimir aquilo que o homem desconhece e foge a seu controle. Revelam o desejo de remodelamento pelo artifício, substituição do orgânico imperfeito pela réplica melhorada. Revelam uma vontade que se impregna no homem a partir do momento de reconhecimento do corpo como matéria e enquanto matéria, tudo que existe. $\mathrm{O}$ rompimento com a transcendência o faz crer apenas no material, sendo assim em seu corpo de carne e osso, tornando-o 
dependente para sua realização e felicidade. Podemos ver isto claramente nas palavras de Silva (2001, p. 39): "a felicidade humana é dependente do corpo seja para sua dominação, seja para sua exaltação".

As alterações no corpo, promovidas pela tecnociência, vêm desvinculando o homem da natureza em direção à artificialidade, propondo que a cultura siga em direção à reconstrução da natureza pela técnica.

\section{CONSIDERAÇÕES FINAIS}

Partindo das reportagens aqui descritas, vemos a ciência percorrendo uma direção eugênica, porém um eugenismo contemporâneo que não mais exclui com a morte os não-arianos. $\mathrm{O}$ novo eugenismo traz uma proposta de inclusão pautada na idéia do artifício, em que o corpo não precisa ter a melhor bagagem genética. Um ser eugênico não é mais aquele que nasce com os melhores genes; agora basta o apoio da ciência para tornar-se eugênico. A melhoria da raça, com exceção das terapias genéticas, adquire características dissimuladoras em que o artifício camufla as imperfeições orgânicas.

As inúmeras técnicas de reprodução assistida apresentam possibilidades de uma eugenia aos moldes daqueles intelectuais de outrora, porém embebida deste nosso contexto.

Frankenstein, nosso personagem moderno, despe-se daquele invólucro para incorporar artifícios internos, invisíveis. A costura não está mais no plano dos segmentos corporais, adentra-se no corpo, nas vísceras, e chega a estruturas mínimas. Denominado Cyborg, "Frank" representa as novas investidas científicas no corpo. Acompanhando o contexto, assume outras conotações, mas persiste a idéia de se criar um ser pós-humano, melhorado, eugenizado.

\section{FRANKENSTEIN AND CYBORGS: INDICATIONS OF NEW EUGENISM THROUGH THE SCIENCE}

\section{ABSTRACT}

This study analyzes the current possibilities of interventions in the body that try enlarge it, turning it better adapted to contemporary conditions. Inspired in Eugenics of the end of the century XIX and beginning of the XX, we intend to look for us elements that help us to think our atmosphere. Through reports collected in newspapers and magazines of great circulation and attentive to the two periods, we identified that new technologies of the body carry permanences of that wel born science: Eugenics. Denominated "new 
eugenism", the current body technologies assume own characteristics of our time, as well as keep deep similarities with science called Eugenia.

KEY-WORDS: eugenics - science - body's adaptations

\section{FRANKENSTEIN Y CYBORGS: HUELLAS EN EL CAMINO DE LA CIÊNCIA QUE ENSEÑAN EL NUEVO EUGENESISMO}

\section{RESUMEN}

Este estudio analiza las posibilidades actuales de intervenciones en el cuerpo las cuales intentan extenderlo y de ahí haciéndolo mucho más adaptado a las condiciones contemporáneas. A través de las lentes de la Eugenesia del final del siglo XIX y comienzo del $\mathrm{XX}$ nos proponemos buscar elementos que nos ayuden a pensar nuestra atmósfera. Teniendo en las manos unos reportajes recolectados de periódicos y revistas de gran circulación y atentos a los dos períodos identificamos que muchas de las nuevas tecnologías del cuerpo traen permanencias de todo lo que fue la búsqueda por el cuerpo mejorado. Denominado "nuevo eugenesismo" las actuales incorporaciones tecnológicas asumen características propias de nuestro tiempo, en cuanto que ellas recogen semejanzas profundas con lo que se ha llamado Eugenesia.

PALABRAS-CLAVE: eugenesia - ciencia - adaptaciones del cuerpo

\section{NOTAS}

1 Este fragmento, de autoria de Mary Shelley, foi extraído do prefácio da obra Frankenstein, literatura britânica datada de 1818.

2 Trecho em que Victor Frankenstein (o criador) revela detalhes do processo de criação de Frankenstein (o monstro).

3 Entenda descobrir no duplo sentido: o de retirar a pele, assim como o de entendê-la e estudá-la.

4 Esta obra é fruto de períodos anteriores como o Iluminismo, que foi o cume de diversas transformações culturais iniciadas no século XIV com o movimento renascentista.

5 Entendemos a eugenia sob dois aspetos, um científico, no qual as teorias eugênicas foram gestadas, e um político, em que os resultados destes estudos chegam a um âmbito público através de medidas estatais.

6 Primo de Francis Galton.

7 Trata-se de um estudo feito com base nos conceitos de distribuição normal ou desvio da média, analisando características biológicas de uma mesma população. Como efeito, revelou que havia regularidade nos resultados obtidos. A partir deste achado Galton vê a possi- 
bilidade de transferi-lo a todas as outras características fisiológicas. Ver mais sobre este assunto em Bizzo (1995).

8 Dentre eles, podemos citar Rembrandt, que pintou "Lições de anatomia”, em 1656; Carlini, que esculpiu "Smugglerios", em 1775; além de Leonardo da Vinci, Michelangelo, Mascagni, Lang e outros.

9 Trecho do diálogo de Frankenstein com seu criador.

10 Ao dizer reinvenção do humano, referimo-nos não só ao aspecto da construção ou reconstrução do corpo anátomo/fisiologicamente, mas também à nova forma de o homem moderno se ver, como um ser individual e material.

11 Criatura pós-humana, que assim se torna quando o homem adota qualquer tipo de tecnologia, um carro, uma prótese, ou faz uso de uma academia de ginástica. O cyborg é possível pelo fato de se conceber o corpo como máquina em busca da per(forma)nce (SILVA, T., 2000). O termo foi definido por um engenheiro e um psiquiatra, tratando-se da abreviação de cybernetic organism. Este termo se refere a um homem "mais bem adaptado", "ampliado para viagens espaciais" (KUNZRU, 2000, p. 133).

12 Victor Frankenstein relatando sobre as honras que receberia por sua vitória contra a morte.

13 Entenda expectativa de vida no sentido espiritual, da vida após a morte carnal, e não como algo puramente material, ligado ao corpo físico.

14 Perspectiva de melhoramento da qualidade e prolongamento de vida, assim como sua produtividade. O desenvolvimento de tais questões fatalmente desemboca na vida material eterna.

15 Entender tais adjetivos no sentido de perfeição dos PCs (BRETON, 2003, p. 123).

16 Entendido como produção de recordes esportivos, corpos mais belos e mais eficientes, assim como produção de novos tipos de vegetais mais resistentes e nutritivos etc.

\section{REFERÊNCIAS}

BIZZO, N. M. V. Eugenia: quando a biologia faz falta ao cidadão. $C a$ derno de Pesquisa, São Paulo, n. 92, p. 38-52, fev. 1995.

BRETON, D. L. Adeus ao corpo. In: NOVAES, A. (Org.). O homemmáquina: a ciência manipula o corpo. São Paulo: Companhia das Letras, 2003. 
CARVALHO, Y. M. de. O mito da atividade física e saúde. 3. ed. São Paulo: Hucitec, 2001.

HOBSBAWM, E. J. A era dos impérios: 1875 - 1914. 3. ed. Rio de Janeiro: Paz e Terra, 1992.

KUNZRU, H. "Você é um cyborg": um encontro com Donna Haraway. In: SILVA, T. T. (Org.). Antropologia do cyborg: as vertigens do póshumano. Belo Horizonte: Autêntica, 2000.

NAFFAH NETO, A. A subjetividade enquanto éthos. Caderno de Subjetividades, São Paulo, v. 3, n. 2, p. 197-200, set.-fev. 1995.

NOVAES, A. A ciência no corpo. In: . (Org.). O homem-máquina: a ciência manipula o corpo. São Paulo: Companhia das Letras, 2003.

SANT'ANNA, D. B. Corpo de passagem: ensaios sobre a subjetividade contemporânea. São Paulo: Estação Liberdade, 2001.

SHELlEY, M. Frankenstein, ou o moderno Prometeu. Trad. de Pietro Nassetti. São Paulo: Martin Claret, 2004.

SILVA, A. M. Corpo, ciência e mercado: reflexões acerca da gestação de um novo arquétipo da felicidade. Campinas: Autores Associados; Florianópolis: UFSC, 2001.

Elementos para compreender a modernidade do corpo numa sociedade racional. Caderno Cedes: Corpo e Educação, Campinas, ano 19, n. 48, ago. 1999.

SILVA, T. T. Nós, cyborgs: o corpo elétrico e a dissolução do humano. In: . (Org.). Antropologia do cyborg: as vertigens do pós-humano. Belo Horizonte: Autêntica, 2000. 
Recebido: 31/03/2005

Aprovado: 01/06/2005

Endereço para correspondência: Rua Serafim de Pinho Ferreira, 96, Apto. 101

Bairro Silvestre

Viçosa - MG

CEP 36570-000

E-mail: andrezaoufv@yahoo.com.br amoreno@ufv.br 
